Article

\title{
Are There Spillovers from China on the Global Energy-Growth Nexus? Evidence from Four World Regions
}

\author{
Luís Miguel Marques ${ }^{1, *}$, José Alberto Fuinhas ${ }^{2}\left[\right.$ and António Cardoso Marques ${ }^{1}(\mathbb{C}$ \\ 1 NECE-UBI, University of Beira Interior (UBI), Rua Marquês d'Ávila e Bolama, 6201-001 Covilhã, Portugal; \\ amarques@ubi.pt \\ 2 NECE-UBI and CeBER, Faculty of Economics, University of Coimbra, 3004-531 Coimbra, Portugal; \\ fuinhas@uc.pt \\ * Correspondence: luis.miguel.marques@ubi.pt
}

Received: 14 January 2019; Accepted: 8 May 2019; Published: 18 June 2019

\begin{abstract}
This paper analyses China's energy consumption and economic growth spillover effects on four world regions: (i) America (North and South); (ii) Europe and Central Asia; (iii) Asia Pacific; and (iv) Africa and the Middle East. An annual aggregated time series by world region, from 1970 to 2016, and an autoregressive distributed lag (ARDL) approach were used. The results are consistent with the feedback hypothesis in the short run. With regard to the long run, feedback is present in America and the Asia Pacific. In Europe and Central Asia and in Africa and the Middle East, the results are consistent with the conservation hypothesis. Additionally, China's spillover effects on the world energy-growth nexus are essentially a long-run phenomenon, with impacts on Europe and Central Asia, Asia Pacific, and Africa and the Middle East. Accordingly, policy-makers should be aware that China's policies may have impact around the world, which indirectly may cause a restriction in economic growth.
\end{abstract}

Keywords: ARDL; China's spillover effects; economic growth; energy-growth nexus; primary energy consumption

JEL Classification: C32; E03; O11; Q43

\section{Introduction}

Over the last few decades, China had the largest growth market for energy, as well as being the second largest consumer of oil and the first primary energy consumer (see Figure 1). China's primary energy consumption rose from around $8 \%$ of world total primary energy consumption to around $23 \%$ from 1990 to 2016. China superseded the United States of America (USA) for the first place in primary energy consumption in 2009, and is still gaining prominence.

Currently, energy is an important factor in globalisation. International trade promotes relationships between countries, namely the energy-dependent ones and the energy producers. With the increasing globalisation in energy markets, it is expected that these relationships will develop further throughout the world in the coming years. For instance, the demand for energy will keep growing in emerging economies. Strong growth in Asia will most likely drive increasing energy consumption and, to satisfy this, some oil producers will play a major role by increasing oil supply. On the one hand, China's primary energy consumption is increasing in recent years, while, on the other hand, it is adjusting its economy to a more sustainable growth pattern by changing from coal to clean energy. 


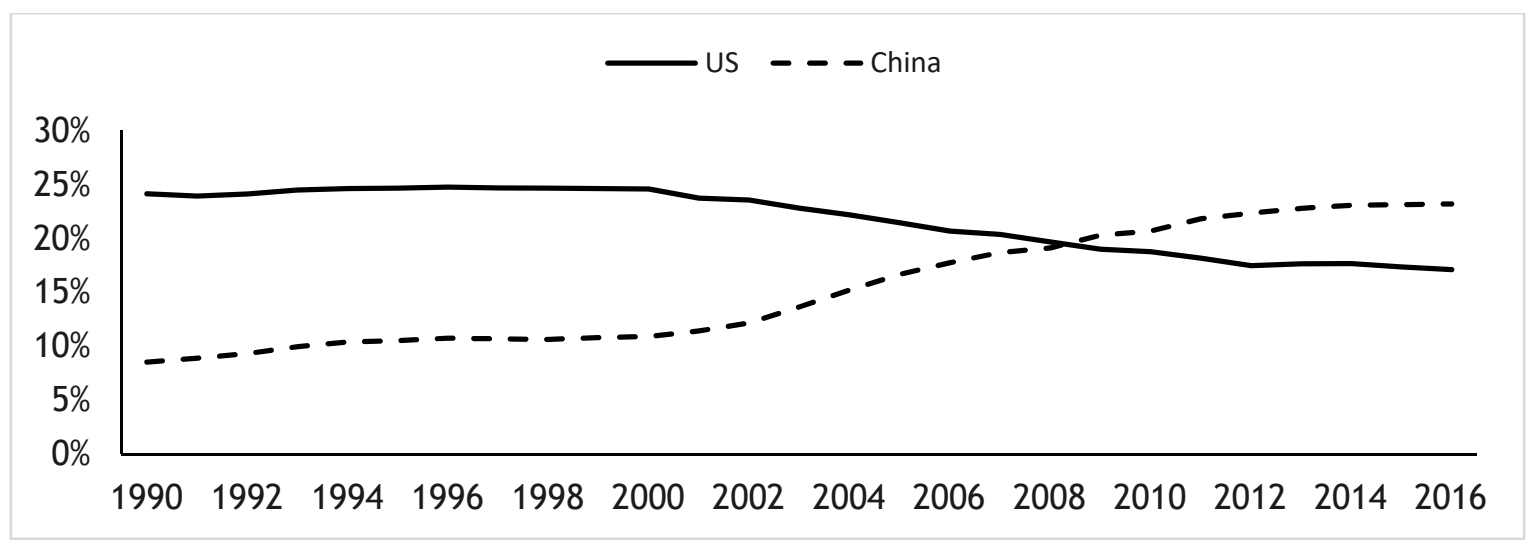

Figure 1. Primary energy consumption in percentage of world total primary energy consumption (BP 2017).

At the 2015 United Nations Climate Change Conference (COP21) summit in Paris in December 2015, the European Union and 195 more countries agreed to limit carbon dioxide emissions in order to restrict global average temperature increases. This agreement incentivised the decarbonisation of energy markets through the diversification of the primary energy sources, namely by switching from oil and coal to gas, while at the same time promoting the renewable ones. World demand for coal slowed, affected by China's reduced demand, which is projected to grow by less than $2 \%$ per year over the next decades, compared with over $6 \%$ per year in the past (BP 2017). This not only reflects China's change in primary energy consumption, but also indicates reduced economic growth. In fact, in 2016, China experienced the slowest rate of energy consumption growth in 20 years.

The facts above, in association with the high and increasing relevance that some players have in the energy markets, may lead to spillover effects on the world energy-growth nexus. Currently, the literature that tries to examine these effects at a world level is scarce. China's case may be especially relevant to trigger interest in the research of spillover effects on the world nexus. With all of this in mind, the following question arises: Is China's changing energy consumption and economic growth causing spillover effects around the world?

This paper aims to study China's spillover effects on the energy-growth nexus, namely China's economic growth and energy consumption impact on the different world regions. While the bulk of the literature usually focuses on the study of the factors that impact on the energy-growth nexus in a given country or group of countries, recent results are consistent with the possibility that some world regions or countries have a greater share of impact on the world nexus, or at least influence the nexus in some regions, given the heterogeneity of results (e.g., Marques et al. 2017b). This is one of the main reasons to test China's economic growth and energy consumption spillover effects on four world regions. Analysing the spillover effects of some specific countries on the world energy-growth nexus could raise a new perspective for policy-makers, namely in what concerns the development of integrated energy policies. Furthermore, it could make a contribution to the augmented energy-growth nexus literature that currently aims to explain the conflicting results in the literature. Research on countries' spillover effects on the energy-growth nexus in the literature is non-existent. However, spillovers could be most likely expected, given the impacts that countries such as the richest ones, the biggest exporting or importing, and the biggest oil producers and consumers can produce.

To answer the main question, an autoregressive distributed lag (ARDL) approach was followed for a time span from 1970 to 2016, and the short-run and long-run elasticities were estimated. The world was divided into four regions (America; Europa and Central Asia; Asia Pacific; and Africa and the Middle East) and the traditional four testable hypotheses related to the energy-growth nexus were evaluated. Furthermore, China's economic growth and energy consumption spillover effects on the four world regions were analysed both in the short and long run. 
The paper evolves as follows: in the next section, there is a brief literature review on energy-growth nexus; in Section 3, data and methodology are shown; the results are presented in Section 4 and discussed in Section 5. Finally, Section 6 encompasses the conclusions.

\section{Literature Review}

The research regarding the relationship between energy consumption and economic growth started when Kraft and Kraft (1978) examined this causality relationship for the United States of America (USA) and found that an increase in gross national product (GNP) caused an increase in energy consumption from 1947 to 1974. Two years later, Akarca and Long (1980) pointed out that the results of Kraft and Kraft (1978) were spurious, by changing the time period by two years. It was the onset of a lack of consensus on the energy consumption and economic growth nexus literature that lasts until the present day. Research on the nexus evolved around the examination of Granger causality between energy and growth (and vice versa), leading to four testable relationships that imply very different energy policy approaches by policy-makers: (i) the neutrality hypothesis, where no relationships between energy and growth are found (e.g., Ahmed and Azam 2016; Glasure and Lee 1998); (ii) the feedback hypothesis, where there is bidirectional causality between energy and growth (e.g., Mohammadi and Parvaresh 2014; Saidi et al. 2017; Streimikiene and Kasperowicz 2016); (iii) the conservation hypothesis, which asserts that there is unidirectional causality running from economic growth to energy consumption (e.g., Ahmed et al. 2015; Alshehry and Belloumi 2015; Islam et al. 2013); and (iv) the growth hypothesis, which asserts that there is causality running from energy consumption to economic growth (e.g., Ahmed and Azam 2016; Narayan and Popp 2012; Wang et al. 2016).

For decades, the energy-growth nexus received considerable attention (e.g., Akarca and Long 1980; Lee and Chang 2007; Wang et al. 2016; Yu and Jin 1992), focusing on dividing the research into single-country and multi-country studies, leading to a mix of results. For example, Wang et al. (2011) found unidirectional causality running from energy consumption to economic growth for China between 1972 and 2006. However, Wang et al. (2016) found bidirectional causality between energy consumption and economic growth for China between 1990 and 2012. Regarding the multi-country studies, it is also possible to find discordant results. Omri and Kahouli (2014) found the presence of bidirectional causality between energy and growth for a panel of high-income countries, while Ahmed and Azam (2016), by studying 24 high-income Organisation for Economic Co-operation and Development (OECD) countries, found bidirectional causality only in five countries, whereby evidence of the impacts running from energy to economic growth was found for four, and no relationships between energy and economic growth were found for 15 countries, respectively. Different methodologies, data, and periods of study are the most advocated causes for heterogeneous results. However, these results reveal that income level may not be directly related to the causality direction in every situation. Furthermore, the use of different methodologies, data, and periods may not be the major causes of heterogeneous results, given that Marques et al. (2017b), when analysing the energy-growth nexus in four comparable world regions, concluded that there were also heterogeneous results. Four generations of methodologies can be identified (e.g., Mehrara 2007): (i) studies based on Vector Autoregression (VAR) methodology (e.g., Sims 1972) and Granger causality, assuming stationarity (e.g., Kraft and Kraft 1978; Yu and Hwang 1984); (ii) studies based on non-stationary series and the Granger (1988) cointegration theory, using an error correction model to test for causality (e.g., Cheng and Lai 1997; Glasure and Lee 1998); (iii) studies using multivariate estimators with more than two variables in the cointegration relationship (e.g., Oh and Lee 2004; Saidi et al. 2017); and (iv) studies based on panel cointegration and panel error correction models (e.g., Mohammadi and Parvaresh 2014; Streimikiene and Kasperowicz 2016).

The nexus research advanced in order to solve new issues that arise, as well as to pursue the causes of the contradictory results, leading to the development of a growing number of articles and the use of different approaches. Research on the energy-growth nexus was extended by including variables such as financial development, population, urbanisation, industrialisation, $\mathrm{CO}_{2}$ emission, and trade openness, among others. For example, Shahbaz and Lean (2012) found that financial 
development, economic growth, industrialisation, and urbanisation increase energy consumption for the Tunisian economy. Islam et al. (2013) results suggest that energy consumption is influenced by economic growth, financial development, and population level for Malaysia. Mirza and Kanwal (2017) found bidirectional causality between energy consumption, economic growth, and $\mathrm{CO}_{2}$ emissions for Pakistan. Recently, globalisation caught researchers' attention. Bidirectional causality between energy consumption and economic growth, energy consumption and trade openness, and economic growth and trade openness was found by Shahbaz et al. (2013) in Indonesia. Marques et al. (2017a) examined the relationships between energy consumption, economic growth, and globalisation for 43 countries and found that globalisation drives both energy consumption and economic growth.

Taking into consideration that globalisation has impacts on the energy-growth nexus, and given that energy markets are becoming increasingly integrated, the study of some countries' spillover effects on the world nexus may not only have relevance, but also lead to a new perspective for policy-makers. Research on spillover effects is far from new in the literature (e.g., Koesler et al. 2016; Mensi et al. 2016; Zhang 2017). However, spillover effect research is absent concerning the world energy-growth nexus.

\section{Data and Methodology}

The paper focuses on the study of the effects of China's economic growth and energy consumption on the energy-growth nexus in four regions: (i) America (North and South); (ii) Europe and Central Asia; (iii) Asia Pacific; and (iv) Africa and the Middle East. The data comprise annual observations from 1970 to 2016. Gross domestic product (Y) and primary energy consumption (E) were extracted from the World Bank's Development Indicators and the BP Statistical Review of World Energy, respectively. $\mathrm{Y}$ is measured in constant 2010 dollars and $\mathrm{E}$ is measured in tonnes of oil equivalent. The use of homogeneous variables is required to meet the goals of applying the same methodology to different regions. In consequence, the data were regrouped to make the variables compatible allowing their comparability. The prefix " $\mathrm{L}$ " denotes the natural logarithm, and " $\mathrm{D}$ " denotes the first difference of variables. Note that the use of the first difference of a $\log$ is equal to a growth rate. EViews 10 econometric software was used. Summary statistics are presented in Table 1.

Table 1. Descriptive statistics.

\begin{tabular}{cccccccccccc}
\hline & \multicolumn{2}{c}{ America } & \multicolumn{4}{c}{$\begin{array}{c}\text { Europe and } \\
\text { Central Asia }\end{array}$} & \multicolumn{2}{c}{ Asia Pacific } & \multicolumn{2}{c}{$\begin{array}{c}\text { Africa and the } \\
\text { Middle East }\end{array}$} & \multicolumn{2}{c}{ China } \\
\hline Statistic & LY & LE & LY & LE & LY & LE & LY & LE & LY & LE \\
\hline Mean & 30.026 & 21.743 & 30.328 & 21.762 & 29.614 & 20.899 & 28.425 & 20.038 & 27.912 & 20.559 \\
Median & 30.258 & 21.747 & 30.326 & 21.772 & 29.699 & 20.942 & 28.329 & 20.090 & 27.896 & 20.535 \\
Maximum & 30.834 & 21.983 & 30.758 & 21.889 & 30.348 & 21.639 & 29.238 & 21.012 & 29.911 & 21.849 \\
Minimum & 29.531 & 21.395 & 29.765 & 21.471 & 28.694 & 20.029 & 27.576 & 18.730 & 26.069 & 19.144 \\
SD & 0.393 & 0.184 & 0.289 & 0.092 & 0.488 & 0.493 & 0.447 & 0.666 & 1.209 & 0.797 \\
Skewness & -0.174 & -0.178 & -0.187 & -1.391 & -0.298 & -0.131 & 0.297 & -0.346 & 0.077 & 0.146 \\
Kurtosis & 1.781 & 1.584 & 1.900 & 5.016 & 1.859 & 1.656 & 2.074 & 2.051 & 1.723 & 1.901 \\
Jarque-Bera & 3.147 & 4.172 & 2.643 & 23.115 & 3.247 & 3.675 & 2.369 & 2.703 & 3.243 & 2.529 \\
Probability & 0.207 & 0.124 & 0.267 & 0.000 & 0.197 & 0.159 & 0.306 & 0.259 & 0.198 & 0.282 \\
Observations & 47 & 47 & 47 & 47 & 47 & 47 & 47 & 47 & 47 & 47 \\
\hline
\end{tabular}

To define the best approach to the study of the dynamics between energy consumption and economic growth and China's economic growth and energy consumption, the variables' order of integration was analysed. Let "YCHN" denote China's gross domestic product and "ECHN" denote China's energy consumption. First of all, a graphical analysis of the level variables and their first differences was conducted (see Figure 2). Secondly, the variables' correlograms were examined (not shown to preserve space). Finally, the Augmented Dickey-Fuller (ADF), Phillips-Perron (PP) and Kwiatkowski-Phillips-Schmidt-Shin (KPSS) unit root tests (see Table 2) and a modified Dickey-Fuller (MDF) unit root test were performed (see Table 3). The MDF test follows Perron (1989) and makes 
it possible to test for the unit root in the presence of a single break date in intercept, trend, or both intercept and trend.

For China, the behaviour shown in Figure 2 is consistent with the possible presence of structural breaks, namely in years 1980, 2000, and 2008. It should be noted that the use of unit root tests with multiple structural breaks was also an option, such as in Gómez et al. (2018). However, we followed a restricted approach given the need to assure that there are enough observations on both sides of the break parameter. Furthermore, if the correlograms and ADF, PP, KPSS, and MDF tests are consistent, there must be robustness in the results.

America
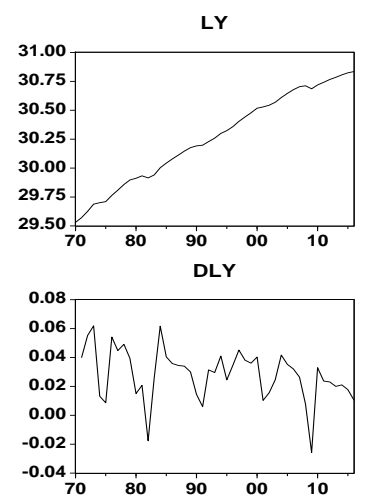
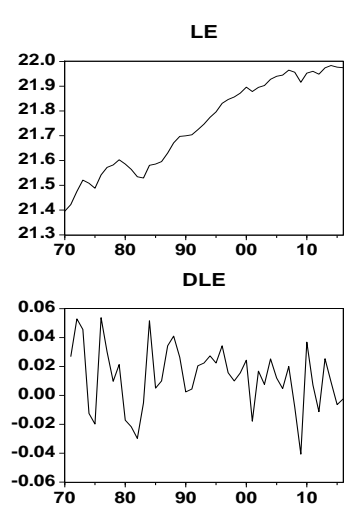

Asia Pacific
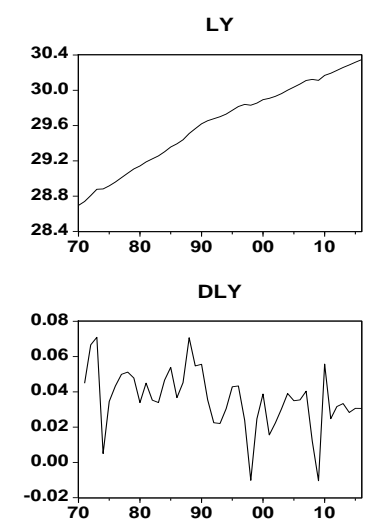

Europe and Central Asia
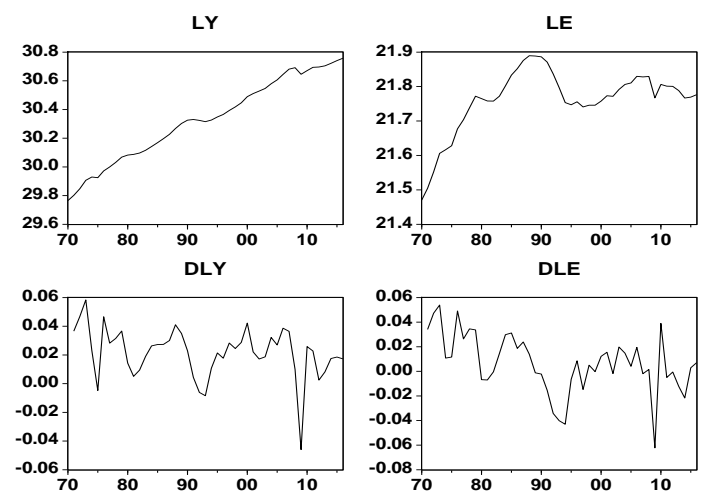

\section{Africa and the Middle East}
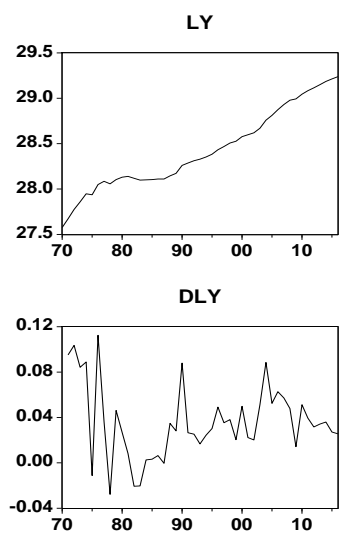

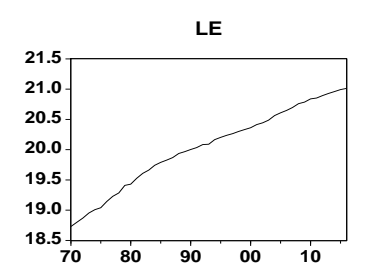

DLE

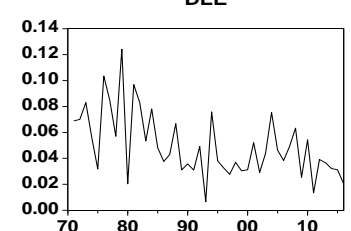

China
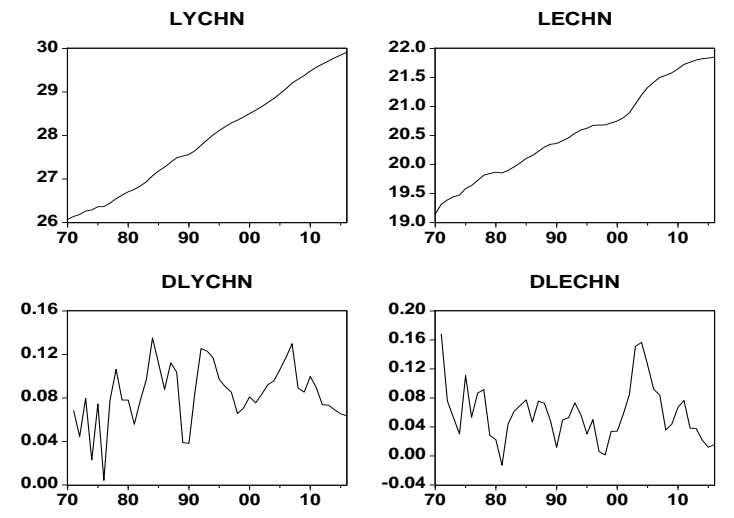

Figure 2. Variables in level and its first differences. 
Table 2. ADF, PP, and KPSS unit root tests.

\begin{tabular}{|c|c|c|c|c|c|c|c|c|c|}
\hline \multicolumn{2}{|c|}{ Regions/Variables } & \multicolumn{3}{|c|}{ ADF } & \multicolumn{3}{|c|}{ PP } & \multicolumn{2}{|c|}{ KPSS } \\
\hline & & (a) & (b) & (c) & (a) & (b) & (c) & (a) & (b) \\
\hline \multirow{3}{*}{ America } & LY & -2.018 & -2.565 & 10.764 & -1.434 & $-3.293 * *$ & 9.180 & $0.193^{* *}$ & $0.892^{* * *}$ \\
\hline & DLY & $-5.064^{* * *}$ & $-4.660^{* * *}$ & $-2.303^{* *}$ & $-4.944^{* * *}$ & $-4.371^{* * *}$ & $-2.004^{* *}$ & 0.097 & 0.397 * \\
\hline & DLE & $-5.607^{* * *}$ & $-5.498^{* * *}$ & $-4.536^{* * *}$ & $-5.542 * * *$ & $-5.421^{* * *}$ & $-4.456^{* * *}$ & 0.067 & 0.231 \\
\hline \multirow{3}{*}{$\begin{array}{l}\text { Europe and } \\
\text { Central Asia }\end{array}$} & LY & -3.063 & -1.619 & 3.483 & -2.567 & -2.138 & 7.187 & $0.132 *$ & $0.890^{* * *}$ \\
\hline & DLY & $-4.856^{* * *}$ & $-4.647^{* * *}$ & $-2.719 * * *$ & $-4.710^{* * *}$ & $-4.533^{* * *}$ & $-2.637^{* * *}$ & 0.057 & 0.316 \\
\hline & DLE & $-4.697^{* * *}$ & $-4.202^{* * *}$ & $-4.105^{* * *}$ & $-4.711^{* * *}$ & $-4.136^{* * *}$ & -4.012 *** & 0.134 * & 0.450 * \\
\hline \multirow{4}{*}{ Asia Pacific } & LY & -1.326 & -3.2 & 4.257 & -1.341 & $-3.283 * *$ & 11.262 & $0.223 * * *$ & $0.886^{* * *}$ \\
\hline & LE & -0.965 & -1.826 & 11.728 & -1.132 & -1.826 & 10.278 & $0.149 * *$ & $0.891^{* * *}$ \\
\hline & DLY & $-5.659 * * *$ & $-4.903^{* * *}$ & -1.497 & $-5.571 * * *$ & $-4.903^{* * *}$ & -1.470 & 0.073 & $0.643 * *$ \\
\hline & DLE & $-5.581^{* * *}$ & $-5.427^{* * *}$ & $-1.675 *$ & $-5.552 * * *$ & $-5.423^{* * *}$ & $-2.109^{* *}$ & 0.099 & 0.308 \\
\hline $\begin{array}{c}\text { Africa and } \\
\text { the Middle } \\
\text { East }\end{array}$ & DLE & -2.455 & -1.696 & -1.348 & $-8.059 * * *$ & $-6.517^{* * *}$ & $-1.956^{* *}$ & 0.122 * & $0.605^{* *}$ \\
\hline \multirow{4}{*}{ China } & LYCHN & $-3.618^{* *}$ & 0.225 & 3.310 & -3.146 & 1.023 & 16.542 & 0.141 * & $0.888^{* * *}$ \\
\hline & LECHN & -2.636 & -0.052 & 2.945 & -2.174 & -0.824 & 6.960 & 0.119 * & $0.883^{* * *}$ \\
\hline & DLYCHN & -3.305 * & $-3.405^{* *}$ & -1.100 & $-4.052^{* *}$ & $-4.012^{* * *}$ & -0.844 & $0.128^{* *}$ & 0.234 \\
\hline & DLECHN & $-3.947 * *$ & $-4.027^{* * *}$ & $-2.620 * * *$ & $-4.013 * *$ & $-4.089^{* * *}$ & $-2.620 * * *$ & 0.083 & 0.088 \\
\hline
\end{tabular}

Notes: (a) denotes the test statistic with the trend and constant; (b) denotes the test statistic with constant; (c) denotes the test statistic without trend and constant. ${ }^{* * *},{ }^{* *}$ and ${ }^{*}$ denote statistical significance at the $1 \%, 5 \%$ and $10 \%$ levels, respectively.

Table 3. Modified Dickey-Fuller (MDF) unit root tests.

\begin{tabular}{cccccc}
\hline Regions & & LY & LE & DLY & DLE \\
\hline \multirow{2}{*}{ America } & T-statistic & $-5.360^{* * *}$ & -2.910 & $-5.881^{* * *}$ & $-7.508^{* * * *}$ \\
& Specification & $(1)$ & $(3)$ & $(4)$ & $(1)$ \\
& Break & 2008 & 1992 & 2007 & 1983 \\
\hline \multirow{3}{*}{ Europe and Central Asia } & T-statistic & -4.124 & -3.647 & $-5.862^{* * *}$ & $-5.569^{* * *}$ \\
& Specification & $(1)$ & $(1)$ & $(4)$ & $(3)$ \\
& Break & 2003 & 1991 & 2009 & 1999 \\
\hline \multirow{2}{*}{ Asia Pacific } & T-statistic & $-5.473^{* * *}$ & -3.707 & $-6.449 * * *$ & $-6.902^{* * *}$ \\
& Specification & $(1)$ & $(3)$ & $(3)$ & $(3)$ \\
& Break & 1989 & 1987 & 2009 & 1982 \\
\hline \multirow{3}{*}{ Africa and Middle East } & T-statistic & $-5.313^{* * *}$ & $-4.585^{* *}$ & $-7.170 * * *$ & $-9.942^{* * * *}$ \\
& Specification & $(3)$ & $(2)$ & $(1)$ & $(4)$ \\
& Break & 1981 & 1984 & 1985 & 1985 \\
\hline \multirow{2}{*}{ China } & T-statistic & -3.680 & -2.978 & $-4.702 * *$ & $-6.013^{* * * *}$ \\
& Specification & $(2)$ & $(1)$ & $(2)$ & $(1)$ \\
& Break & 2015 & 2003 & 1982 & 2002 \\
\hline
\end{tabular}

Notes: Trend specification/break specification: (1) trend and intercept/trend and intercept; (2) trend and intercept/trend only; (3) trend and intercept/intercept only; (4) intercept only/intercept only. ${ }^{* * *}$ and ${ }^{* *}$ denote statistical significance at the $1 \%$ and $5 \%$ levels, respectively.

The variables' behaviour suggests that they are I(1). The correlograms are consistent with the behaviour observed in Figure 2 by supporting that the variables are I(1). Additionally, the ADF, PP, and KPSS tests provide additional information on each variable's order of integration. Further, the MDF test was performed, providing some information regarding the presence of structural breaks.

The ADF, PP, and KPSS tests raise doubts regarding some variables' integration order, such as Asia Pacific growth or Africa and the Middle East energy consumption. Given that some variables may not be I(1) but only near I(1), the ARDL methodology emerges as one of the best choices to cope with variables with possibly different integration orders. 
The MDF test confirms that all variables are at most I(1), as expected. Additionally, it reveals that the 1980 energy crisis, together with the 2008 financial crisis, had impacts in all regions of the world. For those reasons, the ARDL methodology was followed.

The ARDL methodology allows the analyses of both the short-run and the long-run energy-growth nexus. The use of the ARDL approach is far from new in the energy-growth nexus literature (e.g., Farhani and Ozturk 2015; Mirza and Kanwal 2017; Shahbaz et al. 2016). The ARDL methodology has the following advantages: (i) allowing work upon all variables with an integration order lower than two; (ii) permitting robust results to be obtained by correcting outliers and structural breaks; and (iii) allowing the estimation of the long-run elasticities. As noted by Pesaran and Shin (1999), the ARDL approach ensures more consistent results in the case of small samples. Furthermore, the asymptotic theory in the ARDL bounds test approach is not affected by the inclusion of dummy variables (Pesaran et al. 2001). Furthermore, the bounds test allows concluding cointegration among variables even with dummies. It is worthwhile to note that, although the ARDL approach ensures consistent results, the coefficients could be biased in finite samples and, thus, magnified in the calculation of long-run effects (Reed and Zhu 2017). The basic form of an ARDL regression could be represented as follows:

$$
Y_{t}=\gamma_{0}+\gamma_{1} t+\sum_{i=1}^{k} \gamma_{2 i} Y_{t-i}+\sum_{i=0}^{k} \gamma_{3 i} X_{t-i}+\varepsilon_{t}
$$

where $Y$ is the explained variable, $X$ the explanatory variable, $t$ is the trend variable, $\varepsilon_{4 t}$ is the error term, and $k$ represents the number of lags. If the variables are cointegrated, the ARDL can be transformed into an unrestricted error correction model (UECM) in its equivalent ARDL bounds test form as follows:

$$
\Delta Y_{t}=\gamma_{0}+\gamma_{1} t+\sum_{i=1}^{k} \delta_{2 i} \Delta Y_{t-i}+\sum_{i=0}^{k} \delta_{3 i} \Delta X_{t-i}+\delta_{4} Y_{t-1}+\delta_{5} X_{t-1}+\varepsilon_{t}
$$

where $\varepsilon_{5 t}$ denotes the error term. The equivalent general UECM with DLY, DLE, DLYCHN, and DLECHN in its equivalent ARDL bounds test form is as follows:

$$
\begin{gathered}
D L Y_{t}=\alpha_{0}+\alpha_{1} t+\sum_{i=1}^{k} \alpha_{2 i} D L Y_{t-i}+\sum_{i=0}^{k} \alpha_{3 i} D L E_{t-i}+\sum_{i=1}^{k} \alpha_{4 i} \operatorname{DLYCHN}_{t-i}+\sum_{i=0}^{k} \alpha_{5 i} \operatorname{DLECHN}_{t-i} \\
+\alpha_{6} L Y_{t-1}+\alpha_{7} L E_{t-1}+\alpha_{8} \operatorname{LYCHN}_{t-1}+\alpha_{9} \operatorname{LECHN}_{t-1}+\mu_{10 t}
\end{gathered}
$$

where $k$ represents the number of lags defined by empirical knowledge of the variables, and $\mu$ represents the error terms assumed to be white noise and normally distributed. The expected signs of parameters are $\alpha_{0} \neq 0, \alpha_{1} \neq 0, \alpha_{2 i} \neq 0, \alpha_{3 i} \neq 0, \alpha_{4 i} \neq 0, \alpha_{5 i} \neq 0, \alpha_{6}<0, \alpha_{7}>0, \alpha_{8} \neq 0$, and $\alpha_{9} \neq 0$. The parameters $\alpha_{2 i}, \alpha_{3 i}, \alpha_{4 i}$, and $\alpha_{5 i}$ explain the short-run dynamic coefficients, while $\alpha_{6}, \alpha_{7}, \alpha_{8}$, and $\alpha_{9}$ explain the long-run multipliers. On the one hand, a negative $\alpha_{6}$ is expected because it would be consistent with the presence of cointegration. On the other hand, a positive $\alpha_{7}$ is expected, given that a negative coefficient would be consistent with a world curse hypothesis where energy consumption most likely leads to less economic growth, which is highly unlikely.

$$
\begin{gathered}
D L E_{t}=\beta_{0}+\beta_{1} t+\sum_{i=1}^{k} \beta_{2 i} D L E_{t-i}+\sum_{i=0}^{k} \beta_{3 i} D L Y_{t-i}+\sum_{i=0}^{k} \beta_{4 i} D L Y C H N_{t-i}+\sum_{i=0}^{k} \beta_{5 i} D L E C H N_{t-i} \\
+\beta_{6} L E_{t-1}+\beta_{7} L Y_{t-1}+\beta_{8} L_{Y C H N} \operatorname{LCHN}_{t-1}+\beta_{9} L E C H N_{t-1}+\mu_{10 t}
\end{gathered}
$$

where the expected signs of parameters are $\beta_{0} \neq 0, \beta_{1} \neq 0, \beta_{2 i} \neq 0, \beta_{3 i} \neq 0, \beta_{4 i} \neq 0, \beta_{5 i} \neq 0, \beta_{6}<0, \beta_{7}>0$, $\beta_{8} \neq 0$, and $\beta_{9} \neq 0$. The parameters $\beta_{2 i}, \beta_{3 i}, \beta_{4 i}$, and $\beta_{5 i}$ explain the short-run dynamic coefficients, while $\beta_{6}, \beta_{7}, \beta_{8}$, and $\beta_{9}$ explain the long-run multipliers. $\beta_{6}$ is expected to be negative, revealing consistence with the presence of cointegration, and $\beta_{7}$ is expected to be positive, because world economic growth most likely drives the development of productive and non-productive activities, increasing energy consumption. 
To identify the structural breaks that need to be controlled, once more the four-method approach was followed: (i) visual inspection of the model's residuals; (ii) inspection of the Cumulative Sum (CUSUM) and CUSUM of squares tests; (iii) the Quandt-Andrews breakpoint (see Andrews 1993; Andrews and Ploberger 1994) and Bai-Perron multiple breakpoint test (see Bai and Perron 1998; Bai and Perron 2003); and (iv) the Chow breakpoint test. The validity of the models was evaluated through a battery of diagnostic tests: (i) Jarque-Bera normality test; (ii) Breusch-Godfrey serial correlation Lagrange Multiplies (LM) test; (iii) Autoregressive Conditional Heteroskedasticity (ARCH) test for heteroskedasticity; and (iv) Ramsey Regression Equation Specification Error Test (RESET) test for model specification.

Finally, the Granger causality among the variables was evaluated following the Toda and Yamamoto (1995) procedure. To do so, a vector autoregression (VAR) framework was estimated. The maximum lag length was determined by the Akaike and Schwarz information criterions, and the models surpassed all the relevant diagnostic tests revealing no serial correlation, normality, and no heteroskedasticity in the residuals.

\section{Results}

In order to perform the ARDL models, the EViews 10 software was used with lag lengths selected base on the Akaike information selection criterion. We consider $k=1$ as the maximum lag length. We work with annual data and there is increased interest to keep only the first-year differences in the short-run analysis. Furthermore, $k=1$ allows us to avoid any possible problem with the loss of degrees of freedom, and it was revealed to be sufficient to lead to serially uncorrelated errors (see Table 4). The following models were estimated following Equation (3): (i) A-Y, in the case of America; (ii) ECA-Y, for Europe and Central Asia; (iii) AP-Y, for the Asia Pacific; and (iv) AME-Y, for Africa and the Middle East. Similarly, Equation (4) led to the following models: (i) A-E, for America; (ii) ECA-E, for Europe and Central Asia; (iii) AP-E, for the Asia Pacific; and (iv) AME-E, Africa and the Middle East. A first assessment on the model's structural breaks was made by examining the model's residuals (see Figure 3) and CUSUM and CUSUM of squares tests (not shown to preserve space).

The model's residuals are consistent with the presence of structural breaks. Before the breakpoint tests, the CUSUM and CUSUM of squares confirmed the existence of structural breaks. The presence of structural breaks was evident in the models' stability. In accordance with the information revealed by the MDF unit root test, the 1980 oil glut and 2008 great recession impacts were observed across different regions (see Table 5).

Due to the previous lag selection and software limitations, it was not possible to run the Quandt-Andrews and Bai-Perron breakpoint test for the A-Y, AP-E, and AME-Y models. For these cases, there is raised interest in performing the Chow breakpoint test (see Table 6).

Table 4. Diagnostic tests.

\begin{tabular}{ccccccccc}
\hline & A-Y & A-E & ECA-Y & ECA-E & AP-Y & AP-E & AME-Y & AME-E \\
\hline ARS & 0.826 & 0.846 & 0.819 & 0.789 & 0.734 & 0.791 & 0.766 & 0.717 \\
SER & 0.007 & 0.009 & 0.007 & 0.011 & 0.009 & 0.009 & 0.016 & 0.013 \\
JB & 0.145 & 1.995 & 0.984 & 1.134 & 1.115 & 1.279 & 1.152 & 2.265 \\
LM & 0.324 & 2.952 & 2.903 & 1.548 & 2.462 & 2.924 & 2.000 & 0.311 \\
ARCH & 0.413 & 0.263 & 0.012 & 0.109 & 0.090 & 0.482 & 2.051 & 0.003 \\
RESET & 0.555 & 0.061 & 0.178 & 0.583 & 0.383 & 1.120 & 0.029 & 0.374 \\
\hline
\end{tabular}

Notes: Diagnostic tests results are based on F-statistics. ARS means adjusted R-squared. SER means standard error of regression. JB means Jarque-Bera normality test. LM means Breusch-Godfrey serial correlation LM test. ARCH means ARCH test. Reset means Ramsey RESET test. 
A-Y

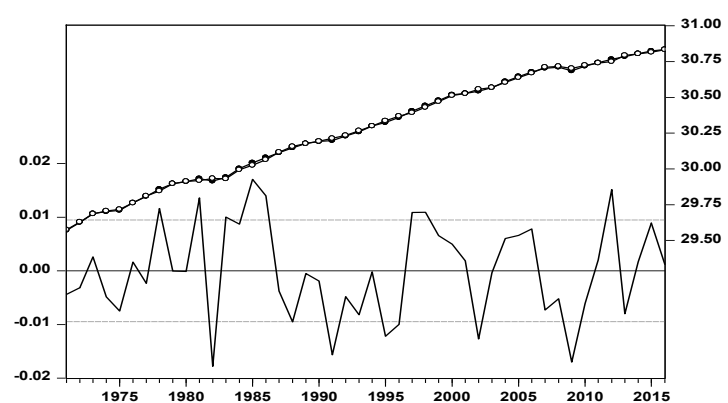

ECA-Y

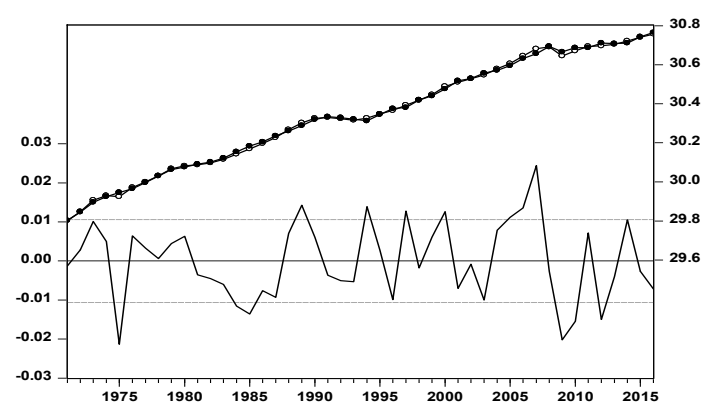

AP-Y

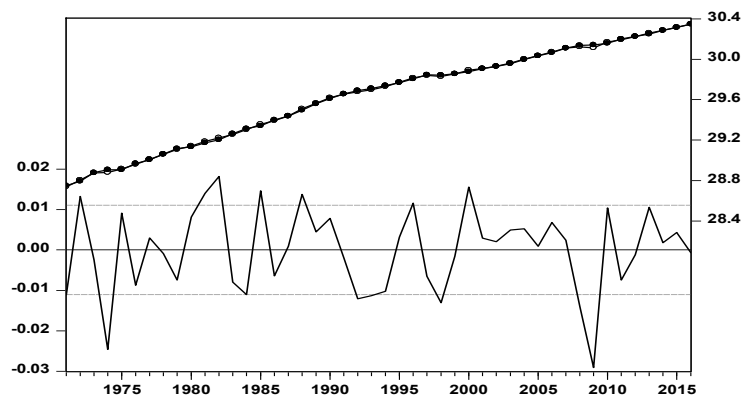

AME-Y

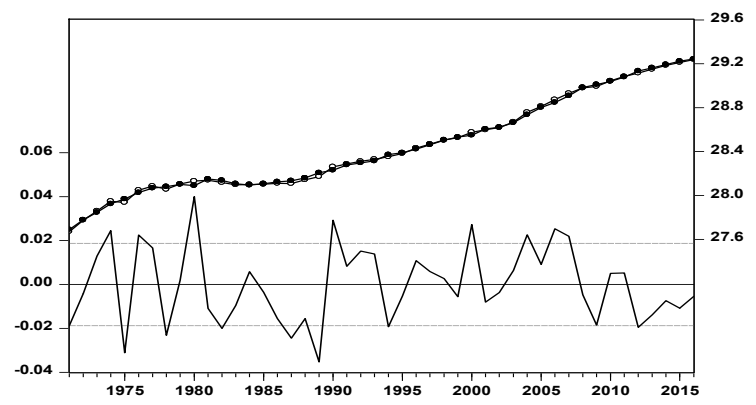

A-E

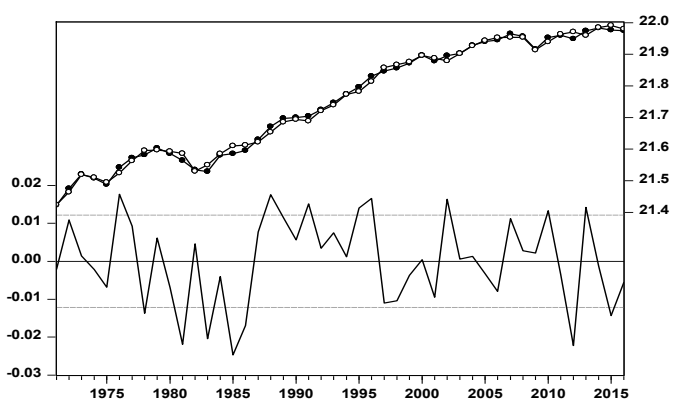

ECA-E

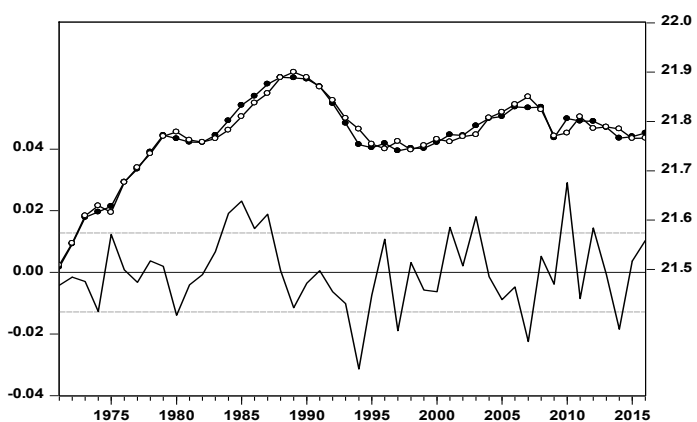

AP-E

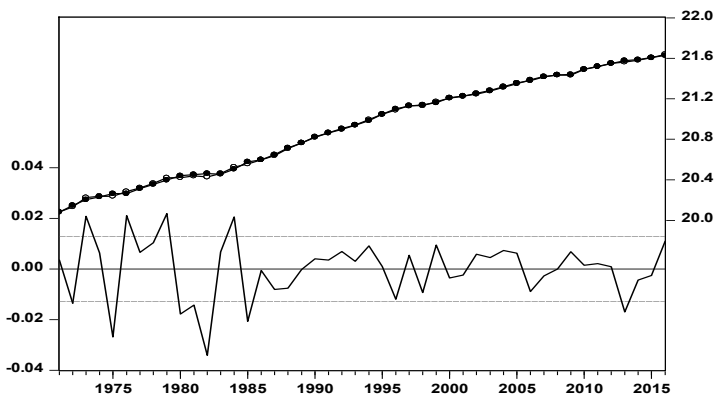

AME-E

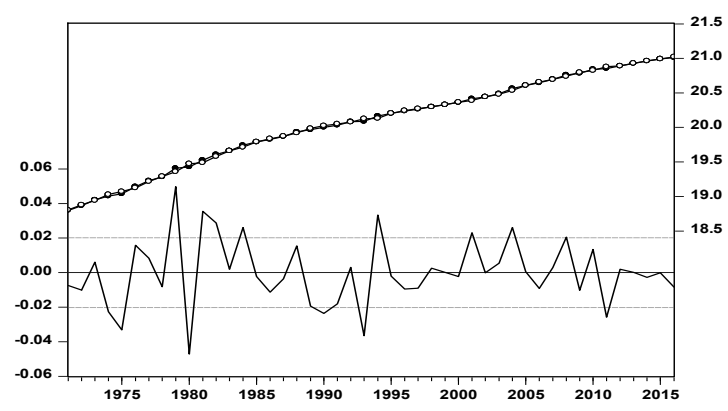

Figure 3. Autoregressive distributed lag (ARDL) residuals. 
Table 5. Quandt-Andrews breakpoint test and Bai-Perron global $l$ breaks vs. none multiple breakpoint test.

\begin{tabular}{|c|c|c|c|}
\hline \multicolumn{4}{|c|}{ Quandt-Andrews Breakpoint Tests } \\
\hline Model & $\begin{array}{c}\text { Maximum Likelihood-ratio (LR) } \\
\text { F-statistics }\end{array}$ & $\begin{array}{c}\text { Maximum } \\
\text { Wald F-statistic }\end{array}$ & Break date \\
\hline$A-Y$ & - & - & - \\
\hline A-E & $5.560 * * *$ & $33.359 * * *$ & 1987 \\
\hline ECA-Y & $3.252 *$ & $19.509 *$ & 2009 \\
\hline ECA-E & $4.565^{* * *}$ & $22.823^{* * *}$ & 1989 \\
\hline AP-Y & $3.555 * *$ & $21.329 * *$ & 1992 \\
\hline AP-E & - & - & - \\
\hline AME-Y & - & - & - \\
\hline AME-E & $8.449^{* * *}$ & $42.244^{* * *}$ & 1981 \\
\hline \multicolumn{4}{|c|}{ Bai-Perron Global Break vs. None Multiple Breakpoint Tests } \\
\hline Model & Scaled F-statistic & \multicolumn{2}{|c|}{ Estimated break dates } \\
\hline$A-Y$ & - & \multicolumn{2}{|c|}{-} \\
\hline A-E & $60.434 * *$ (5 breaks) & \multicolumn{2}{|c|}{ 1979; 1985; 1994; 2002; 2011} \\
\hline ECA-Y & $190.412 * *$ ( 5 breaks $)$ & \multicolumn{2}{|c|}{ 1980; 1988; 1995; 2001; 2011} \\
\hline ECA-E & $76.507 * *(5$ breaks $)$ & \multicolumn{2}{|c|}{ 1977; 1988; 1994; 2000; 2010} \\
\hline AP-Y & $126.500 * *$ ( 5 breaks $)$ & \multicolumn{2}{|c|}{ 1978; 1984; 1990; 2000; 2009} \\
\hline AP-E & - & \multicolumn{2}{|l|}{-} \\
\hline AME-Y & - & \multicolumn{2}{|l|}{-} \\
\hline AME-E & $50.038^{* *}(2$ breaks $)$ & \multicolumn{2}{|c|}{$1980 ; 1988$} \\
\hline
\end{tabular}

Table 6. Chow breakpoint test.

\begin{tabular}{ccccccccc}
\hline Date & A-Y & A-E & ECA-Y & ECA-E & AP-Y & AP-E & AME-Y & AME-E \\
\hline 1979 & 0.644 & 1.087 & 1.065 & 0.445 & $2.312^{*}$ & $2.455^{* *}$ & $2.665^{* *}$ & $2.770^{* *}$ \\
1980 & 0.616 & 1.190 & 1.196 & 0.446 & $3.528^{* * *}$ & $5.482^{* * *}$ & $2.571^{* *}$ & $3.158^{* *}$ \\
1981 & $3.392^{* * *}$ & 1.189 & 1.322 & 0.775 & $2.706^{* *}$ & $4.929^{* * *}$ & $3.379^{* * *}$ & $8.449^{* * *}$ \\
1989 & 1.660 & 1.627 & 1.567 & $4.565^{* * *}$ & $2.850^{* *}$ & $5.351^{* * *}$ & $2.513^{* *}$ & $3.047^{* *}$ \\
1990 & 1.697 & 1.489 & 0.328 & $2.422^{*}$ & $2.978^{* *}$ & $5699^{* * *}$ & $2.982^{* *}$ & $2.593^{* *}$ \\
1991 & 1.801 & 1.692 & 0.224 & $2.265^{*}$ & $3.280^{* *}$ & $4.920^{* * *}$ & $1.989^{*}$ & $2.064^{*}$ \\
\hline
\end{tabular}

Notes: F-statistic values. ${ }^{* * *},{ }^{* *}$, and ${ }^{*}$ denote statistical significance at the $1 \%, 5 \%$, and $10 \%$ levels, respectively.

It was not possible to carry out the Chow breakpoint test at the beginning of the series. Moreover, the Chow breakpoint test was not used to confirm the possible breaks arising from the 2008 financial crisis because, closer to the end of the series, the robustness of the test decreases. For both cases, some shift dummies were tested for their adequacy in the models, taking the models' residuals and the statistical significance of the dummies as a guide. The Chow breakpoint test was used to test for structural breaks arising from the 1980 energy crisis and 1990 oil price shock, revealing that the Asia Pacific and Africa and the Middle East experienced impacts in both periods. Additionally, the period of 1990 should also be analysed for the Europe and Central Asia aggregate.

Taking into account all the collected information on possible structural breaks, the shift dummies for those periods were tested. The non-statistically significant variables were removed. Additionally, there was a need to control some outliers with impulse dummies. The models were kept as narrow as possible. The residuals of the corrected models (see Figure 4) show greater stability compared to Figure 3. Additionally, it is possible to observe no implication on the residuals for the fitted models. The results of the ARDL models are shown in Table 7.

The error correction mechanism (ECM) coefficients were negatively and statistically significant, which is consistent with the presence of cointegration. It should be said that the model ECA-E only revealed statistical significance at the $10 \%$ level. Notwithstanding, the presence of cointegration was assessed by the ARDL bounds test. 
A-Y

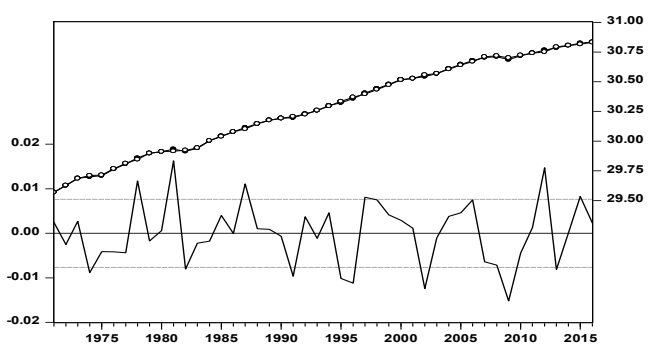

ECA-Y

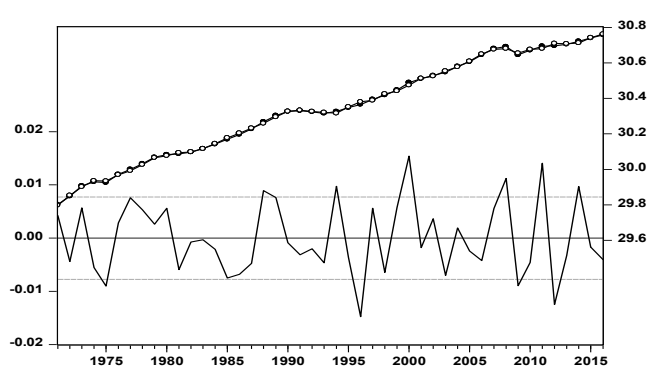

AP-Y

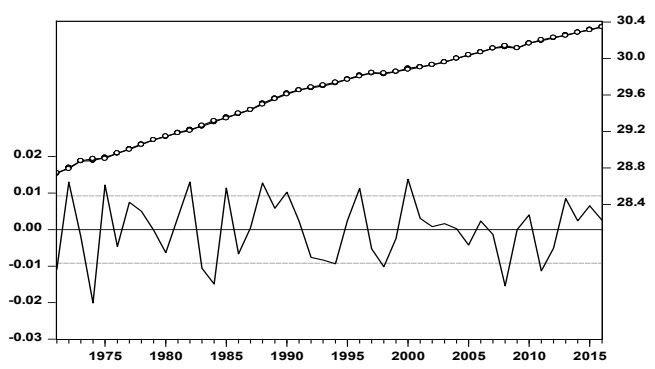

AME-Y

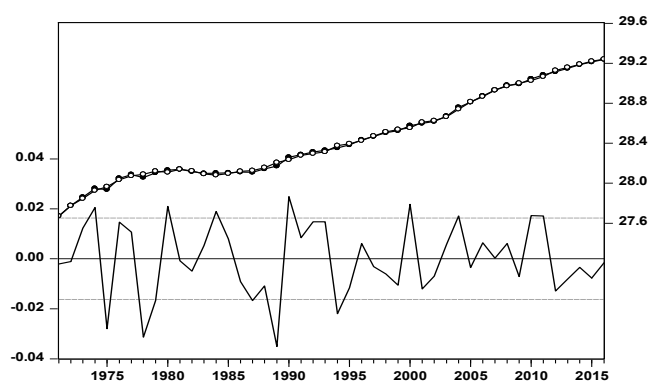

A-E

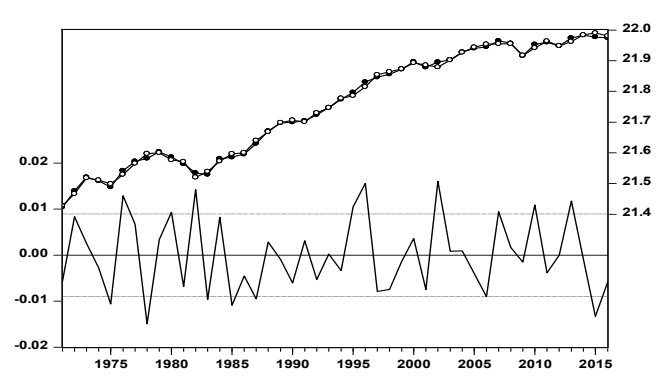

ECA-E

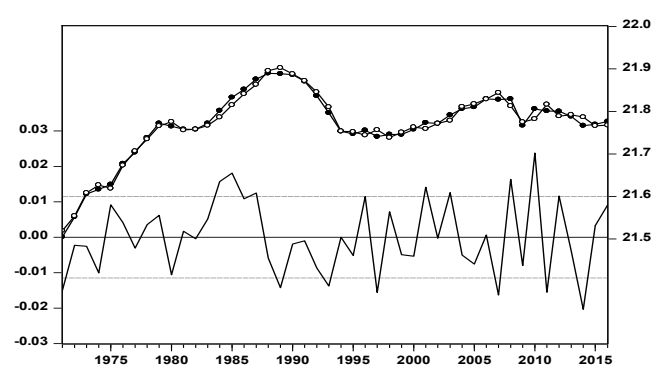

AP-E

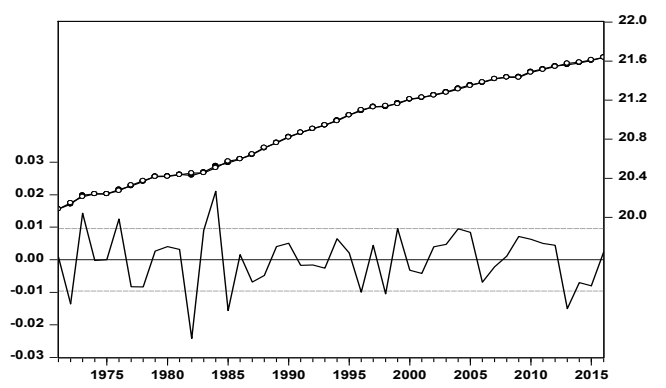

AME-E

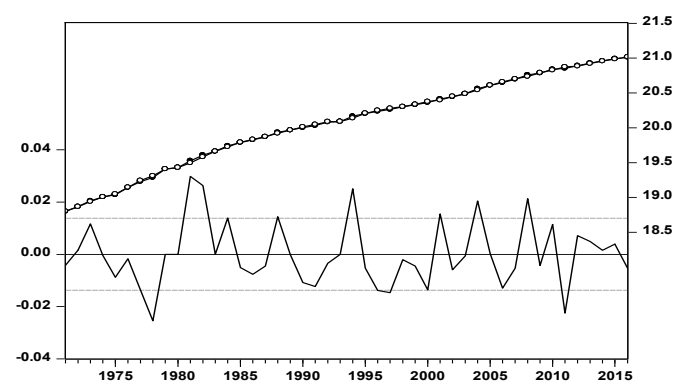

- Residual - - Actual -o- Fitted

Figure 4. ARDL residuals with dummies controlling for the shocks. 
Table 7. Autoregressive distributed lag (ARDL) models.

\begin{tabular}{|c|c|c|c|c|c|c|c|c|}
\hline & $A-Y$ & A-E & ECA-Y & ECA-E & AP-Y & AP-E & AME-Y & AME-E \\
\hline Constant & $-1.565^{* *}$ & $2.515^{* * *}$ & $3.029^{* * *}$ & - & $2.121^{* * *}$ & $-6.001^{* * *}$ & $4.656^{* * *}$ & - \\
\hline Trend & - & - & - & - & - & $-0.009 * *$ & - & - \\
\hline DLE & $0.699 * * *$ & - & $0.594^{* * *}$ & - & $0.582 * * *$ & - & $0.378^{* *}$ & - \\
\hline DLYCHN & - & - & -0.069 & - & - & $0.191 * * *$ & $-0.463^{* * *}$ & $0.252 * *$ \\
\hline DLECHN & - & - & -0.041 & $0.112 * *$ & - & - & 0.066 & - \\
\hline LYCHN(-1) & - & - & 0.028 * & - & - & $0.102 * * *$ & $0.063 * *$ & 0.019 \\
\hline LECHN(-1) & - & - & $0.052 * *$ & 0.015 & - & - & $0.191^{* * *}$ & - \\
\hline LYCHN & 0 & 0.002 & - & -0.031 * & -0.015 & - & - & - \\
\hline LECHN & 0.011 & 0 & - & - & $0.059 * * *$ & $-0.051 * *$ & - & -0.007 \\
\hline ECM & $-0.146^{* * *}$ & $-0.261^{* * *}$ & $-0.226^{* * *}$ & $-0.074 *$ & $-0.142 * *$ & $-0.194^{* * *}$ & $-0.276^{* * *}$ & $-0.097^{* * *}$ \\
\hline SD8316 & $0.025^{* * *}$ & - & - & - & - & - & - & - \\
\hline SD8016 & - & $-0.029 * * *$ & - & - & - & - & - & - \\
\hline ID2012 & - & $-0.022 * *$ & - & - & - & - & - & - \\
\hline & A-Y & A-E & ECA-Y & ECA-E & AP-Y & AP-E & AME-Y & AME-E \\
\hline \multicolumn{9}{|c|}{ Time Dummies } \\
\hline \multicolumn{9}{|c|}{ Europe and Central Asia } \\
\hline SD0916 & - & - & - & $-0.014^{*}$ & - & - & - & - \\
\hline SD0816 & - & - & $-0.039^{* * *}$ & - & - & - & - & - \\
\hline SD7516 & - & - & $-0.016^{* *}$ & - & - & - & - & - \\
\hline ID1994 & - & - & - & $-0.033^{* * *}$ & - & - & - & - \\
\hline SD8116 & - & - & - & - & - & - & -0.033 * & - \\
\hline SD7616 & - & - & - & - & - & - & - & $0.051^{* * *}$ \\
\hline ID1993 & - & - & - & - & - & - & - & $-0.042^{* * *}$ \\
\hline ID1980 & - & - & - & - & - & - & - & $-0.056^{* * *}$ \\
\hline ID1979 & - & - & - & - & - & - & - & $0.034 * *$ \\
\hline
\end{tabular}

Notes: SD means shift dummy and ID means impulse dummy. ${ }^{* * *}, * *$, and ${ }^{*}$ denote statistical significance at the $1 \%$, $5 \%$, and $10 \%$ levels, respectively.

With regard to the structural breaks, for the America case, impacts were observed from the second oil shock (1979) and the 1987 stock market crash. For Europe and Central Asia, impacts were observed for the 2008 financial crisis by causing a decrease in both economic growth and energy consumption. Furthermore, the year of 1990 revealed no need for a shift dummy, but 1994 needed to be controlled with an impulse dummy. Asia Pacific needed to be controlled for the second oil shock (1979 onwards) and the years of 1975 and 2009. In Africa and the Middle East, impacts on the nexus from the first and second oil shocks were also observed. Additionally, Africa and the Middle East needed to be controlled for several disturbances in the nexus which were revealed in the model's residuals and controlled by using impulse dummies.

The models revealed normally distributed errors, no serial correlation in the residuals, and no autoregressive conditional heteroskedasticity (see Table 4), with statistical significance at the $5 \%$ level. Additionally, the possibility of serial correlation in the A-E, ECA-Y, AP-Y, and AP-E models was analysed in detail using the correlograms. No statistically significant autocorrelation was revealed. To confirm the presence of cointegration, the ARDL bounds test was performed (see Table 8). 
Table 8. Bounds test.

\begin{tabular}{ccccccccc}
\hline & A-Y & A-E & ECA-Y & ECA-E & AP-Y & AP-E & AME-Y & AME-E \\
\hline F-statistic & $5.662^{* * *}$ & $7.162^{* * *}$ & $10.890^{* * *}$ & $12.217^{* * *}$ & $7.822^{* * *}$ & $9.207^{* * *}$ & $20.897^{* * *}$ & $20.965^{* * *}$ \\
\hline
\end{tabular}

Notes: $k=3$, where $\mathrm{k}$ represents the number of independent variables in the equation estimated. Critical values were obtained from Pesaran et al. (2001). Critical values for no intercept and no trend for the bottom and top are, respectively, 3.42 and 4.84, for 1\%; 2.45 and 3.63, for 5\%; and 2.01 and 3.10, for $10 \%$. Critical values for unrestricted intercept and no trend for the bottom and top are, respectively, 4.29 and 5.61, for 1\%; 3.23 and 4.35, for 5\%; and 2.72 and 3.77 , for $10 \%$. Critical values for unrestricted intercept and restricted trend for the bottom and top are, respectively, 4.3 and 5.23 , for $1 \%$; 3.38 and 4.23 , for $5 \%$; and 2.97 and 3.74 , for $10 \%$. ${ }^{* * *}$ denotes statistical significance at the $1 \%$ level.

All the models revealed the presence of cointegration at the $1 \%$ significance level. To examine the impacts of China's energy consumption and economic growth on the four aggregates, the short-run and the long-run elasticities were examined (see Table 9).

Table 9. Short-run and long-run elasticities.

\begin{tabular}{ccccccccc}
\hline & A-Y & A-E & ECA-Y & ECA-E & AP-Y & AP-E & AME-Y & AME-E \\
\hline Short-run & & & & & & & & \\
DLY & - & $0.969^{* * *}$ & - & $0.946^{* *}$ & - & $0.796^{* * *}$ & - & $0.275^{* * *}$ \\
DLE & $0.699^{* * *}$ & - & $0.594^{* * *}$ & - & $0.582^{* * *}$ & - & $0.378^{* * *}$ & - \\
DLYCHN & - & - & -0.069 & - & - & - & $-0.463^{* * *}$ & $0.252^{* *}$ \\
DLECHN & - & - & -0.041 & $0.11^{* *}$ & - & - & 0.066 & - \\
\hline Long-run & & & & & & & & $0.557^{* * *}$ \\
LY & - & $0.388^{* * *}$ & - & $0.955^{* * *}$ & & $1.477^{* * *}$ & - & - \\
LE & $1.820^{* * *}$ & - & $0.412^{* * *}$ & - & 0.439 & - & $-0.438^{*}$ & 0.191 \\
LYCHN & 0.003 & 0.009 & $0.124^{* *}$ & $-0.421^{* *}$ & -0.107 & $0.528^{* * *}$ & $-0.229^{* *}$ & 0.1906 \\
LECHN & 0.072 & 0.002 & $0.229^{* *}$ & 0.208 & $0.412^{* *}$ & $-0.044^{* * *}$ & $0.692^{* * *}$ & -0.067 \\
\hline
\end{tabular}

Notes: ${ }^{* * *},{ }^{* *}$, and ${ }^{*}$ denotes statistical significance at the $1 \%, 5 \%$, and $10 \%$ levels, respectively.

Some short-run elasticities were not shown given that, in the model optimization, the lagged variables were removed due to their statistical non-significance. The relationships between the variables were only considered for those with elasticities statistically significant at the $5 \%$ level, at least. In the short run, the elasticities are consistent with a bidirectional causality between energy consumption and economic growth, while, in the long run, most likely, there is bidirectional causality for the America and Europe and Central Asia aggregates. For the Asia Pacific and Africa and the Middle East aggregates, the results show that economic growth has positive impacts on energy consumption.

With regard to China's energy consumption, it was observed that it only has a positive impact for Europe and Central Asia in terms of energy consumption, in the short run. In the long run, an increase in China's energy consumption would promote economic growth in Europe and Central Asia, Asia Pacific, and Africa and the Middle East, while hurting economic growth in Asia Pacific. China's increasing economic growth would lead to energy consumption in Africa and the Middle East, while negatively affecting economic growth, in the short run. In the long run, economic growth in China most likely would increase economic growth in Europe and Central Asia. The same would be seen in the Asia Pacific. However, it can also be observed that, while China's economic growth hurts energy consumption in Europe and Central Asia, it promotes economic growth in Africa and the Middle East.

To confirm the presence of causal relationships between the variables, the Toda and Yamamoto (1995) procedure was followed. The results are shown in Table 10.

Overall, the Toda and Yamamoto (1995) procedure results were consistent with those found in the ARDL elasticities. Bidirectional causality between energy consumption and economic growth was found for the Americas, Europe and Central Asia, and Africa and the Middle East. In Asia Pacific, a unidirectional causality running from economic growth to energy consumption was found. China's economic growth causes energy consumption in Europe and Central Asia, as well as economic growth 
in the Asia Pacific. China's energy consumption causes both energy consumption and economic growth for the Americas, Europe and Central Asia, and the Asia Pacific, as well as energy consumption in Africa and the Middle East. It should be said that, despite causality being found between China's energy consumption and both energy consumption and economic growth for the Americas, their elasticities revealed no statistical significance. These results are discussed in the next section.

Table 10. Granger causality/block exogeneity Wald tests.

\begin{tabular}{ccccccccc}
\hline & \multicolumn{2}{c}{ Americas } & \multicolumn{2}{c}{ Europe and Central Asia } & \multicolumn{2}{c}{ Asia Pacific } & \multicolumn{2}{c}{ Africa and the Middle East } \\
\hline & LY & LE & LY & LE & LY & LE & LY & - \\
LY & - & $12.956^{* * *}$ & - & $6.784^{* *}$ & - & $7.508^{* *}$ & $8.468^{* *}$ & - \\
LE & $6.083^{* *}$ & - & $8.667^{* * *}$ & - & 3.311 & - & $11.965^{* * *}$ \\
LYCHN & 1.761 & 0.526 & 0.568 & $9.441^{* * *}$ & $6.866^{* *}$ & 0.548 & 0.482 & 2.972 \\
LECHN & $20.876^{* * *}$ & $7.174^{* *}$ & $16.223^{* * *}$ & $28.373^{* * *}$ & $20.246^{* * *}$ & $11.053^{* * *}$ & 1.061 & $13.565^{* * *}$ \\
\hline
\end{tabular}

Notes: ${ }^{* * *}$ and ${ }^{* *}$ denote statistical significance at the $1 \%$ and $5 \%$ levels, respectively.

\section{Discussion}

The paper's main goal was to contribute to the analysis of China's economic growth and energy consumption spillover effects on the world nexus, which is non-existent in the literature. Energy consumption plays an important role in determining economic development. Energy is not only used in production, but is also consumed as an output for increasing welfare. It is one of the key factors that directly or indirectly determines the production structures of countries, competitiveness in international markets, budget balances, current account deficits, and economic growth rates (Esen and Bayrak 2017). In turn, the energy markets are often affected by supply, demand, imports, exports, financial speculation, and major changes in global oil supplies, among others. Accordingly, not only are relationships between energy consumption and economic growth expected to impact on the energy-growth nexus all over the world, but they would also change in a major oil consumer such as China. For these reasons, any research into the impact of China's economic growth and energy consumption on the world nexus can make a significant contribution, enabling policy-makers to understand the extent to which China's policies affect other countries, as they seek to achieve sustainable world growth and joint energy policies.

The use of the ARDL bounds test approach proved to be of particular interest given the presence of cointegration. On the one hand, by following the ARDL methodology, it was possible to examine both the short-run and the long-run effects of China's economic growth and energy consumption on four aggregates (America; Europe and Central Asia; Pacific Asia; Africa and the Middle East). On the other hand, it makes it possible to compare the results with those obtained by Marques et al. (2017b), and, by being concordant, confirms the model's robustness. The results are not only consistent with the short-run and the long-run energy-growth nexus found by Marques et al. (2017b), but are also consistent in their historical impacts, namely in the 1980 oil crisis and 2008 great recession.

Using the ARDL bounds test approach, with annual time series data from 1970 to 2016, the observed results agreed with the traditional feedback hypothesis on the energy-growth nexus across the world, in the short run. Additionally, feedback was observed for America, and Europe and Central Asia, in the long run. In the Asia Pacific, and Africa and the Middle East, the results were consistent with the growth hypothesis. The breakpoint tests revealed the existence of instability in the models. Despite this, a parsimonious approach led to the introduction of a reduced number of dummies. It should be said that, for the Asia Pacific aggregate, fewer periods needed to be controlled, most likely because China was removed from the aggregate.

When regarding the spillover effects of China's economic growth and energy consumption on the world nexus (see Figure 5), only the America aggregate seems to be immune to any impacts. The United States (US) is the weightiest country in the America aggregate, and a Chinese economic slowdown may represent a decrease in US exports and, consequently, an increasing deficit in the balance of trade. However, this effect is most likely counteracted by a decrease in oil prices, given that 
a Chinese economic slowdown leads to a reduction in energy consumption, which most likely leads to an oil price reduction due to the increased supply. These joint effects probably explain the immunity seen in the America aggregate. However, a disaggregated analysis is advisable. By analysing country by country, not only will it be possible to analyse immunity to the possible energy-growth spillovers in each country, but it will also allow a more in-depth analysis in the US. The spillovers are essentially a long-run phenomenon, most likely impacting the aggregates' nexus over several years, given the slow speed of adjustment to the long-run equilibrium. Overall, the results make us aware that China's increased growth and energy consumption may have some negative impacts on energy consumption in Europe, Central Asia, and the Asia, and it may even affect African and Middle Eastern growth. Given that this is the first assessment of China's impacts on the world nexus, further detailed research is advisable to fully understand the impacts, especially the negative ones. This research should most likely be extended to other groups, such as the top oil producers or top oil consumers.
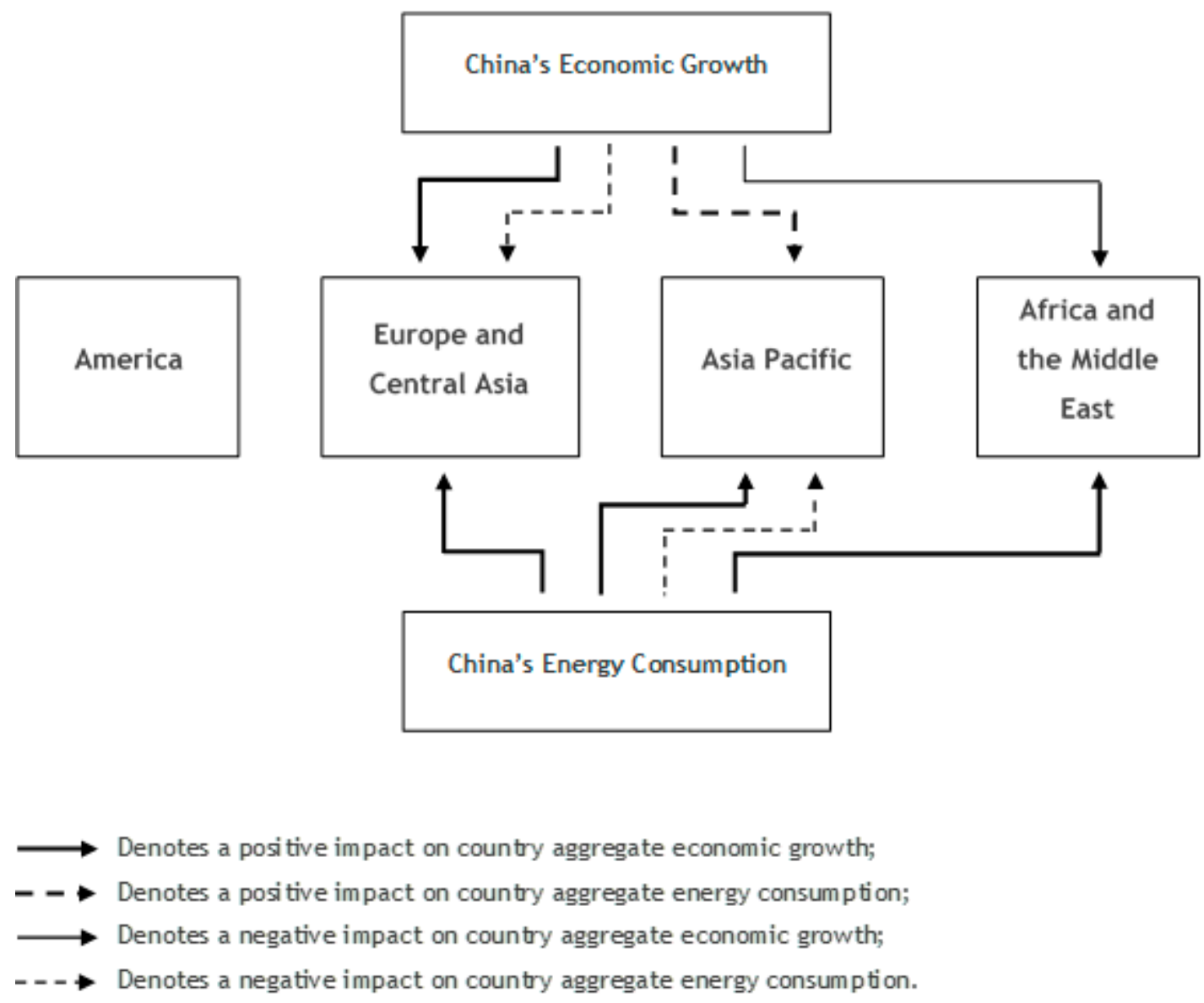

Figure 5. Summary scheme of long-run behaviours.

In the end, a group of countries may have the power to create a world recession, for example, China's primary energy suppliers. On the one hand, by creating internal reserves management policies, China will withdraw supremacy over primary energy producers because China has energy import dependence, and if for some reason China's energy consumption and economic growth are restricted, that will most likely impact the world nexus and, consequently, influence development. On the other hand, China's policy-makers should be aware that their decisions have world impacts, and every country should take into account China's impact on their policies, namely countries from Europe and Central Asia and Africa and the Middle East, who can experience negative impacts from China's policies, as stated earlier. To cope with this, agreements must be reached that contribute to economic stability and help Europe and Central Asia to counteract any possible negative impacts. 
Our results support the International Energy Agency_IEA (2017) statements which assert that China's choices will play a huge role in determining global trends. This should have special importance for Europe and Central Asia where policy-makers most likely need to ensure that energy consumption is not reduced by China's economic growth by promoting the economies' independence in terms of energy consumption. For example, an increasingly renewable energy path is advisable to promote energy security. It will not only help make the economies less dependent on oil imports, but it is also compatible with some global goals such as the 2030 Sustainable Development agenda or the Paris Agreement. Furthermore, the increasing development of renewables in Europe and Central Asia will promote an economic diversification that will help make the economies more responsive to shocks by improving the adjustment speed of the energy-growth nexus. The slow speed of adjustment of the energy-growth nexus is evident in the entire research.

Furthermore, from an energy security point of view, diversification should be promoted in countries such as China and India, countries that are going to be increasingly import-dependent over the next few decades. The results also assist policy-makers by revealing that restrictive energy policies are discouraged for America, and Europe and Central Asia, because they will most likely hamper economic growth. Oppositely, in Africa and the Middle East, energy exports will likely be the path to follow given that these are compatible with China's energy consumption and also to protect against a possible effect of the "natural resources curse", where an excess of energy resources constrains economic growth.

\section{Conclusions}

The impact of China's energy consumption and economic growth on the energy-growth nexus was analysed in four world regions: America; Europe and Central Asia; Pacific Asia; and Africa and the Middle East. By using an ARDL approach, with annual time series data from 1970 to 2016, behaviours were analysed both in the short run and long run. The results reveal that China's spillover effect is essentially a long-run phenomenon, and only America was not affected by China's economic growth or increased energy consumption.

The results highlight that, in the long run, China's growth will most likely reduce Europe's and Central Asia's energy consumption, which indirectly may cause a restriction in economic growth. Moreover, African and Middle Eastern growth may be hampered by China's growth. The energy-growth nexus in the studied world regions supports the creation of integrated energy policies, namely for America and for Europe and Central Asia. On the one hand, America is the only region where no spillover effect from China was verified, and this fact can be seen as an incentive to develop independent policies. On the other hand, both America and Europe and Central Asia have similar nexus behaviours; thus, no restrictive energy policies should be followed because they are likely to hamper economic growth, and their effects may persist for years.

The results support the fact that countries should not be indifferent to the policies that China may follow, particularly for Europe and Central Asia where energy growth will most likely be reduced by China's growth. Policy-makers should be aware that China's policies may impact around the world, which indirectly may cause a restriction in economic growth. Additionally, African and Middle Eastern growth seems to be negatively influenced by China's growth. For this reason, to devise policies jointly is advisable. Europe and Central Asia must ensure that energy consumption is not reduced by China's economic growth, while Africa and the Middle East most likely need to maintain or promote energy exports. Taking this into account, the results support the development of integrated energy polices. Moreover, for those countries that will play a dominant role in energy markets, it should be important to create blocs to ensure that no country negatively influences the market. Additionally, economic diversification is widely recommended.

In the future, it is advisable to disaggregate the analysis through single-country studies, namely for countries in the America aggregate where neutrality was found, for example, just analysing the spillover effects on the US. What is more, it is increasingly important to understand the spillover effects 
of other regions or countries on the world energy-growth nexus, namely those with either high shares of world gross domestic product (GDP), the biggest exporting or importing, or the top oil producers and consumers.

Author Contributions: Methodology, L.M.M.; software, L.M.M.; investigation, L.M.M.; writing—original draft preparation, L.M.M.; writing - review and editing, J.A.F. and A.C.M.

Acknowledgments: The financial support of the NECE-Research Unit in Business Science and Economics, project UID/GES/04630/2019, and through the fellowship SFRH/BD/120003/2016, sponsored by the FCT-Portuguese Foundation for the Development of Science and Technology, Ministry of Science, Technology, and Higher Education is acknowledged. We thank the three anonymous reviewers for their useful comments and suggestions.

Conflicts of Interest: The authors declare no conflict of interest.

\section{References}

Ahmed, Mumtaz, and Muhammad Azam. 2016. Causal nexus between energy consumption and economic growth for high, middle and low income countries using frequency domain analysis. Renewable and Sustainable Energy Reviews 60: 653-78. [CrossRef]

Ahmed, Mumtaz, Khalid Riaz, Atif Maqbool Khan, and Salma Bibi. 2015. Energy consumption-economic growth nexus for Pakistan: Taming the untamed. Renewable and Sustainable Energy Reviews 52: 890-96. [CrossRef]

Akarca, Ali T., and Thomas Veach Long. 1980. On the Relationship Between Energy and GNP: A Reexamination. The Journal of Energy and Development 5: 326-31.

Alshehry, Atef Saad, and Mounir Belloumi. 2015. Energy consumption, carbon dioxide emissions and economic growth: The case of Saudi Arabia. Renewable and Sustainable Energy Reviews 41: 237-47. [CrossRef]

Andrews, Donald W. K. 1993. Tests for Parameter Instability and Structural Change with Unknown Change Point. Econometrica 61: 821-56. [CrossRef]

Andrews, Donald W. K., and Werner Ploberger. 1994. Optimal Tests when a Nuisance Parameter is Present Only Under the Alternative. Econometrica 62: 1383-414. [CrossRef]

Bai, Jushan, and Pierre Perron. 1998. Estimating and Testing Linear Models with Multiple Structural Changes. Econometrica 66: 47-78. [CrossRef]

Bai, Jushan, and Pierre Perron. 2003. Computation and analysis of multiple structural change models. Journal of Applied Econometrics 18: 1-22. [CrossRef]

BP. 2017. BP Energy Outlook. Available online: https://www.bp.com/content/dam/bp/pdf/energy-economics/ energy-outlook-2017/bp-energy-outlook-2017.pdf (accessed on 18 July 2017).

Cheng, Benjamin S., and Tin Wei Lai. 1997. An investigation of co-integration and causality between energy consumption and economic activity in Taiwan. Energy Economics 19: 435-44. [CrossRef]

Esen, Ömer, and Metin Bayrak. 2017. Does more energy consumption support economic growth in net energy-importing countries? Journal of Economics, Finance and Administrative Science 22: 75-98. [CrossRef]

Farhani, Sahbi, and Ilhan Ozturk. 2015. Causal relationship between $\mathrm{CO}_{2}$ emissions, real GDP, energy consumption, financial development, trade openness, and urbanization in Tunisia. Environmental Science and Pollution Research 22: 15663-76. [CrossRef] [PubMed]

Glasure, Yong U., and Aie-Rie Lee. 1998. Cointegration, error-correction, and the relationship between GDP and energy: The case of South Korea and Singapore. Resource and Energy Economics 20: 17-25. [CrossRef]

Gómez, Mario, Aitor Ciarreta, and Ainhoa Zarraga. 2018. Linear and Nonlinear Causality between Energy Consumption and Economic Growth: The Case of Mexico 1965-2014. Energies 11: 784. [CrossRef]

Granger, Clive. 1988. Some recent development in a concept of causality. Journal of Econometrics 39: 199-211. [CrossRef]

IEA. 2017. World Energy Outlook 2017. Available online: https://www.iea.org/Textbase/npsum/weo2017SUM.pdf (accessed on 1 June 2018).

Islam, Faridul, Muhammad Shahbaz, Ashraf U. Ahmed, and Md Mahmudul Alam. 2013. Financial development and energy consumption nexus in Malaysia: A multivariate time series analysis. Economic Modelling 30: 435-41. [CrossRef]

Koesler, Simon, Kim Swales, and Karen Turner. 2016. International spillover and rebound effects from increased energy efficiency in Germany. Energy Economics 54: 444-52. [CrossRef] 
Kraft, John, and Arthur Kraft. 1978. On the Relationship Between Energy and GNP. The Journal of Energy and Development 3: 401-03.

Lee, Chien-Chiang, and Chun-Ping Chang. 2007. The impact of energy consumption on economic growth: Evidence from linear and nonlinear models in Taiwan. Energy 32: 2282-94. [CrossRef]

Marques, Luís Miguel, José Alberto Fuinhas, and António Cardoso Marques. 2017a. Augmented energy-growth nexus: Economic, political and social globalization impacts. Energy Procedia 136: 97-101. [CrossRef]

Marques, Luís Miguel, José Alberto Fuinhas, and António Cardoso Marques. 2017b. On the dynamics of energy-growth nexus: Evidence from a world divided into four regions. International Journal of Energy Economics and Policy 7: 208-15.

Mehrara, Mohsen. 2007. Energy consumption and economic growth: The case of oil exporting countries. Energy Policy 35: 2939-45. [CrossRef]

Mensi, Walid, Shawkat Hammoudeh, Duc Khuong Nguyen, and Sang Hoon Kang. 2016. Global financial crisis and spillover effects among the U.S. and BRICS stock markets. International Review of Economics E Finance 42: 257-76. [CrossRef]

Mirza, Faisal Mehmood, and Afra Kanwal. 2017. Energy consumption, carbon emissions and economic growth in Pakistan: Dynamic causality analysis. Renewable and Sustainable Energy Reviews 72: 1233-40. [CrossRef]

Mohammadi, Hassan, and Shahrokh Parvaresh. 2014. Energy consumption and output: Evidence from a panel of 14 oil-exporting countries. Energy Economics 41: 41-46. [CrossRef]

Narayan, Paresh Kumar, and Stephan Popp. 2012. The energy consumption-real GDP nexus revisited: Empirical evidence from 93 countries. Economic Modelling 29: 303-8. [CrossRef]

Oh, Wankeun, and Kihoon Lee. 2004. Energy consumption and economic growth in Korea: Testing the causality relation. Journal of Policy Modeling 26: 973-81. [CrossRef]

Omri, Anis, and Bassem Kahouli. 2014. Causal relationships between energy consumption, foreign direct investment and economic growth: Fresh evidence from dynamic simultaneous-equations models. Energy Policy 67: 913-22. [CrossRef]

Perron, Pierre. 1989. The Great Crash, the Oil Price Shock, and the Unit Root Hypothesis. Econometrica 57: $1361-401$. [CrossRef]

Pesaran, M. Hashem, and Yongcheol Shin. 1999. An Autoregressive Distributed-Lag Modelling Approach to Cointegration Analysis. In Econometrics and Economic Theory in the 20th Century: The Ragnar Frisch Centennial Symposium. Edited by Steinar Strøm. Cambridge: Cambridge University Press, pp. 371-413.

Pesaran, M. Hashem, Yongcheol Shin, and Richard J. Smith. 2001. Bounds testing approaches to the analysis of level relationships. Journal of Applied Econometrics 16: 289-326. [CrossRef]

Reed, W. Robert, and Min Zhu. 2017. On estimating long-run effects in models with lagged dependent variables. Economic Modelling 64: 302-11. [CrossRef]

Saidi, Kais, Mohammad Mafizur Rahman, and Mounira Amamri. 2017. The causal nexus between economic growth and energy consumption: New evidence from global panel of 53 countries. Sustainable Cities and Society 33: 45-56. [CrossRef]

Shahbaz, Muhammad, and Hooi Hooi Lean. 2012. Does financial development increase energy consumption? The role of industrialization and urbanization in Tunisia. Energy Policy 40: 473-79. [CrossRef]

Shahbaz, Muhammad, Qazi Muhammad Adnan Hye, Aviral Kumar Tiwari, and Nuno Carlos Leitão. 2013. Economic growth, energy consumption, financial development, international trade and $\mathrm{CO}_{2}$ emissions in Indonesia. Renewable and Sustainable Energy Reviews 25: 109-21. [CrossRef]

Shahbaz, Muhammad, Hrushikesh Mallick, Mantu Kumar Mahalik, and Perry Sadorsky. 2016. The role of globalization on the recent evolution of energy demand in India: Implications for sustainable development. Energy Economics 55: 52-68. [CrossRef]

Sims, Christopher A. 1972. Money, Income, and Causality. The American Economic Review 62: 540-52.

Streimikiene, Dalia, and Rafał Kasperowicz. 2016. Review of economic growth and energy consumption: A panel cointegration analysis for EU countries. Renewable and Sustainable Energy Reviews 59: 1545-49. [CrossRef]

Toda, Hiro. Y., and Taku Yamamoto. 1995. Statistical inference in vector autoregressions with possibly integrated processes. Journal of Econometrics 66: 225-50. [CrossRef]

Wang, Yuan, Yichen Wang, Jing Zhou, Xiaodong Zhu, and Genfa Lu. 2011. Energy consumption and economic growth in China: A multivariate causality test. Energy Policy 39: 4399-406. [CrossRef] 
Wang, Shaojian, Qiuying Li, Chuanglin Fang, and Chunshan Zhou. 2016. The relationship between economic growth, energy consumption, and $\mathrm{CO}_{2}$ emissions: Empirical evidence from China. Science of The Total Environment 542: 360-71. [CrossRef]

Yu, Eden S. H., and Been-Kwei Hwang. 1984. The relationship between energy and GNP: Further results. Energy Economics 6: 186-90. [CrossRef]

Yu, Eden S. H., and Jang C. Jin. 1992. Cointegration tests of energy consumption, income, and employment. Resources and Energy 14: 259-66. [CrossRef]

Zhang, Youguo. 2017. Interregional carbon emission spillover-feedback effects in China. Energy Policy 100: 138-48. [CrossRef]

(C) 2019 by the authors. Licensee MDPI, Basel, Switzerland. This article is an open access article distributed under the terms and conditions of the Creative Commons Attribution (CC BY) license (http://creativecommons.org/licenses/by/4.0/). 